\title{
PENINGKATAN KINERJA PEGAWAI DITINJAU DARI KOMPETENSI, INSENTIF DAN DISIPLIN DI BALAI PENGELOLAAN SUMBER DAYA AIR BENGAWAN SOLO
}

\author{
Swarma Andriyana ${ }^{1}$, Istiatin ${ }^{2}$, Ratna Damayanti ${ }^{3}$ \\ Islam Batik University of Surakarta, Jl. Agus Salim No.10, Surakarta \\ andriyana.ay08@gmail.com
}

\begin{abstract}
The research aims to find out and describe the influence of either simultaneously or partial competence, incentive and dicipline to employees performance in Balai PSDA Bengawan Solo. This research using quantitative descriptive research. The population was all employees at Balai PSDA Bengawan Solo totaled 77. The number of samples is 77 respondents. Sampling method using sensus sampling. The questionnaire used for data retrieval. Data analysis technique used was statistic analysis. This $F$ test results the competence, incentive and dicipline simultaneously and significant effect on employees performance in Balai PSDA Bengawan Solo. The t-test results showed that the competence influential positive and significant effect against the employees performance in Balai PSDA Bengawan Solo. Incentive influential positive and significant effect against the employees performance in Balai PSDA Bengawan Solo. Regression multiple linier model in this research is $\mathrm{Y}=0,142+0,586 \mathrm{X}_{\mathrm{K}}+0,199 \mathrm{X}_{\mathrm{I}}+0,227 \mathrm{X}_{\mathrm{D}}+\mathrm{e}$.
\end{abstract}

Keywords: Employees Performance, Competence, Incentive, Dicipline

\section{PENDAHULUAN}

Saat ini, dalam meningkatkan pelayanan kepada masyarakat dibutuhkan pengembangan sumber daya manusia. Menjalankan tugas dengan baik sangat bergantung pada keberhasilan mengembangkan sumber daya manusia. Kinerja pegawai dapat menjadi faktor kegagalan ataupun keberhasilan dalam melakukan pekerjaan. Balai PSDA Bengawan Solo dituntut untuk dapat mengembangkan sumber daya manusia yang memiliki kualitas dan juga dapat memanfaatkan perkembangan ilmu pengetahuan dan teknologi untuk mengembangkan saluran irigasi.

Kemampuan untuk melakukan pekerjaan yang didasarkan pada pengetahuan, sikap dan keterampilan merupakan salah satu faktor kompetensi. Pegawai yang memiliki kompetensi tinggi dapat mempengaruhi produktivitasnya dalam bekerja. Dengan adanya penetapan standar kompetensi dapat mempengaruhi kinerja baik secara kelompok atau individu. Selain kompetensi, insentif dapat mempengaruhi peningkatan kinerja pegawai. Insentif merupakan salah satu bentuik dorongan pada pegawai untuk lebih berprestasi lagi dalam bekerja. Pegawai yang memiliki disiplin yang tinggi dapat menjalankan pekerjaannnya dengan baik yang mampu menaati peraturan yang ada di perusahaan. Dalam mencapai pekerjaan yang maksimal, salah satu modal yang harus dimiliki seorang pegawai adalah kedisiplinan.

Balai PSDA Bengawan Solo yang berlokasi di Jl. Monginsidi No.74 Banjarsari, Surakarta, Jawa Tengah bergerak dibidang penyediaan irigasi pertanian di seluruh wilayah karesidenan Surakarta meliputi Klaten, Sukoharjo, Wonogiri, Sragen, Karanganyar dan Boyolali. Pelayanan irigasi antara lain pengaturan pasokan air, operasional dan pemeliharaan saluran air, penerapan musim tanam dikelola dengan baik. Hal ini harus ditunjang oleh pegawai yang memilikmi keterampilan dibidangnya mulai dari tenaga administrasi sampai tenaga teknis lapangan. 
Mengingat pentingnya kebutuhan sumber daya air keperluan irigasi, maka dibutuhkan sistem pengelolaan baik dan koordinasi dengan pihak terkait. Hasil yang maksimal dapat ditentukan oleh pegawai yang memiliki prestasi dalam menyelesaikan sebuah pekerjaan. Pegawai yang memiliki peran di lingkungan Balai PSDA Bengawan Solo harus mendapatkan apresiasi dari pimpinan melalui peningkatan kompetensi, insentif dan disiplin kerja yang mampu mewujudkan pegawai yang terampil. Dari uraian di atas penulis berpendapat layak untuk melakukan penelitian dengan judul : Analisis Kompetensi, Insentif dan Disiplin Terhadap Kinerja Pegawai Balai PSDA Bengawan Solo.

\section{LANDASAN TEORI}

Chandrawati., et al (2013) mengatakan bahwa kinerja pada dasarnya adalah apa yang dilakukan atau tidak dilakukan pegawai atau kelompok dalam organisasi sesuai dengan tanggung jawab dalam mencapai tujuan organisasi yang sesuai dengan aturan yang berlaku. Kompetensi adalah karakteristik dasar seseorang dalam berfikir dan bertindak, membuat generalisasi terhadap segala situasi yang dihadapi dalam waktu yang lama (Sutrisno, 2014: 203). Candrawati., et al (2013) mengatakan bahwa insentif dapat digunakan untuk menarik orang-orang yang potensial dan berkualitas untuk berkontribusi pada pekerjaan. Disiplin merupakan ketaatan setiap pegawai terhadap semua aturan yang berlaku dilingkungan kerja masing-masing yang mampu mewujudkan sikap perilaku dan perbuatan yang bisa menciptakan situsi harmonis dalam mencapai tujuan (Prihantoro, 2012). Adapun kerangka berpikir dalam penelitian ini adalah:

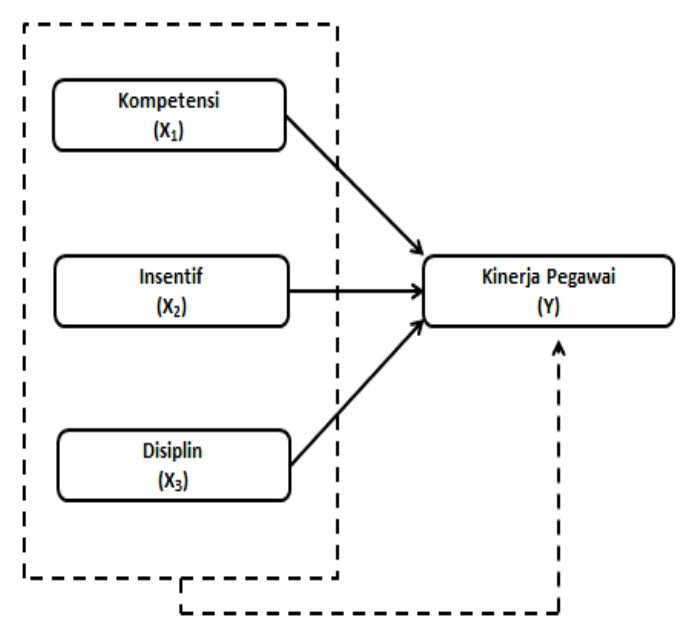

Gambar 2.1 Kerangka Berpikir

\section{METODOLOGI PENELITIAN}

Penelitian menggunakan pendekatan deskriptif kuantitatif. Tempat penelitian di Balai PSDA Bengawan Solo yang berlokasi di Jl. Monginsidi No.74 Banjarsari, Surakarta, Jawa Tengah. Populasinya adalah pegawai Balai PSDA Bengawan Solo yang berjumlah 77 orang. Dalam menentukan jumlah sampel digunakan pendapat Arikunto (2016: 116) yang menyatakan jika populasi kurang dari 100, maka diambil semuanya. Jadi sampel penelitian ini sejumlah 77 orang. Teknik sampling menggunakan metode sampling sensus. Kuesioner digunakan untuk pengambilan data. Regresi linier berganda sebagai metode untuk menganalisis data. 
4. HASIL DAN PEMBAHASAN

Uji Asumsi Klasik

\section{Hasil uji normalitas}

Menguji normalitas digunakan alat analisis Kolmogorov-Smirnov, hasilnya adalah:

Tabel 1

Hasil Uji Normalitas

\begin{tabular}{|c|c|c|}
\hline & $\begin{array}{c}\text { Unstandarized } \\
\text { Residual }\end{array}$ & Keterangan \\
\hline$N$ & 77 & \multirow{3}{*}{$\begin{array}{c}\text { Data } \\
\text { terdistribusi } \\
\text { normal }\end{array}$} \\
\hline $\begin{array}{l}\text { Kolmogrov- } \\
\text { Smirnov Z }\end{array}$ & .620 & \\
\hline $\begin{array}{c}\text { Asymp.Sig (2 } \\
\text { tailed) }\end{array}$ & .837 & \\
\hline
\end{tabular}

Hasil uji Kolmogrov Smirnov menunjukkan nilai Asymp. Sig. $(0,837)>0,05$. Artinya persamaan regresi memiliki sebaran data yang normal.

\section{Hasil uji multikolinearitas}

Hasil yang di dapatkan adalah:

Tabel 2

\begin{tabular}{|c|c|c|}
\hline \multicolumn{3}{|c|}{ Hasil Uji Multikolinearitas } \\
\hline \multirow[t]{2}{*}{ Model } & \multicolumn{2}{|c|}{$\begin{array}{c}\text { Collinearity } \\
\text { Statistics }\end{array}$} \\
\hline & $\begin{array}{c}\text { Toleran } \\
\text { ce }\end{array}$ & $V I F$ \\
\hline $\begin{array}{l}\text { Kompeten } \\
\text { si }\end{array}$ & .599 & 1.671 \\
\hline Insentif & .690 & 1.449 \\
\hline Disiplin & .744 & 1.344 \\
\hline
\end{tabular}

Berdasarkan tabel di atas menunjukkan hasil dari pengujian multikolinearitas, nilai VIF dari kompetensi $(1,671)$, insentif $(1,449)$ dan disiplin $(1,344)$ yang memliki nilai VIF < 10. Jadi tidak terdapat adanya multikolinieritas.

\section{Hasil uji heteroskedastisitas}

Hasil yang di dapatkan dalam uji heteroskedastisitas adalah:

Tabel 3

Hasil Uji Heterokedastisitas

\begin{tabular}{ccc}
\hline Model & Sig. & Keterangan \\
\hline Kompete & .61 & Tidak terjadi \\
nsi & 5 & heterokedastisitas \\
Insentif & .41 & Tidak terjadi \\
& 0 & heterokedastisitas \\
Disiplin & .98 & Tidak terjadi \\
& 0 & heterokedastisitas \\
\hline
\end{tabular}


Berdasarkan tabel di atas dari hasil output SPSS menunjukkan bahwa nilai sig. kompetensi $0,615>0,05$, nilai sig. insentif $0,410>0,05$ dan nilai sig. disiplin $0,980>0,05$. Model regresi ini tidak terjadi adanya heteroskedastisitas.

\section{Hasil Analisis Data}

\section{Regresi linier berganda}

Nilai a dan $b_{1}, b_{2}, b_{3}$ dalam uji regresi linier berganda adalah:

Tabel 4

\begin{tabular}{|c|c|c|}
\hline \multirow[t]{2}{*}{ Model } & \multicolumn{2}{|c|}{$\begin{array}{c}\text { Unstandardized } \\
\text { Coefficients }\end{array}$} \\
\hline & $B$ & Std. Error \\
\hline (Constant) & .142 & 1.594 \\
\hline $\begin{array}{l}\text { Kompeten } \\
\text { si }\end{array}$ & .586 & .094 \\
\hline Insentif & 199 & .095 \\
\hline Disiplin & .227 & .091 \\
\hline
\end{tabular}

Berdasarkan tabel di atas diperoleh persamaannya adalah:

$\mathrm{Y}=0,142+0,586 \mathrm{X}_{\mathrm{K}}+0,199 \mathrm{X}_{\mathrm{I}}+0,227 \mathrm{X}_{\mathrm{D}}+\mathrm{e}$

\section{Uji F}

Perhitungan nilai $\mathrm{F}_{\text {hitung }}$ adalah:

Tabel 5

Hasil Uji F

\begin{tabular}{llcc}
\hline Model & $F$ & Sig. & $\begin{array}{c}\text { Keteranga } \\
\mathrm{n}\end{array}$ \\
\hline \multicolumn{1}{l}{ Regressi } & 43.19 & $.000^{\mathrm{a}}$ & $\mathrm{H}_{0}$ ditolak, \\
on & 7 & & $\mathrm{H}_{1}$ \\
& Residual \\
Total & & & diterima \\
\hline
\end{tabular}

Hasil uji serempak dengan program SPSS, diketahui besarnya nilai $F_{\text {hitung }}>F_{\text {tabel }}(43,197)>$ $(2,73)$, nilai signifikan $0,000<0,05$, jadi $\mathrm{H}_{1}$ diterima, kompetensi, insentif dan disiplin secara signifikan dan simultan mempengaruhi kinerja pegawai Balai PSDA Bengawan Solo.

\section{Uji t}

Perhitungan uji $t_{\text {hitung }}$ adalah:

Tabel 6

Hasil Uji t

\begin{tabular}{|c|c|c|c|c|}
\hline Model & B & $\mathrm{t}$ & Sig. & Keterangan \\
\hline Kompetensi & .586 & 6.216 & .000 & $\begin{array}{c}\mathrm{H}_{2} \\
\text { diterima }\end{array}$ \\
\hline Insentif & .199 & 2.102 & .039 & $\begin{array}{c}\mathrm{H}_{3} \\
\text { diterima }\end{array}$ \\
\hline Disiplin & .227 & 2.483 & .015 & $\begin{array}{c}\mathrm{H}_{4} \\
\text { diterima }\end{array}$ \\
\hline
\end{tabular}


Pada variabel motivasi hasil nilai $t_{\text {hitung }}(6,216)>t_{\text {tabel }}(1,993)$ dengan signifikansi $0,000<$ $0,05, \mathrm{H}_{2}$ diterima, berarti kompetensi berpengaruh secara positif dan signifikan kinerja pegawai Balai PSDA Bengawan Solo.

Pada variabel insentif hasil nilai $t_{\text {hitung }}(2,102)>t_{\text {tabel }}(1,993)$ dengan signifikansi $0,039<$ $0,05, \mathrm{H}_{3}$ diterima, berarti insentif berpengaruh secara positif dan signifikan kinerja pegawai Balai PSDA Bengawan Solo.

Pada variabel pelatihan kerja hasil nilai $t_{\text {hitung }}(2,483)>t_{\text {tabel }}(1,993)$ dengan signifikansi $0,015<0,05, \mathrm{H}_{4}$ diterima, berarti disiplin berpengaruh secara positif dan signifikan kinerja pegawai Balai PSDA Bengawan Solo.

\section{Koefisien determinasi}

Perhitungan nilai koefisien determinasi adalah:

Tabel 7

Hasil Koefisien Determinasi

\begin{tabular}{ccc}
\hline$R$ & $R$ Square & Adjusted $R$ Square \\
\hline $.800^{\mathrm{a}}$ & .640 & .625 \\
\hline
\end{tabular}

Nilai Adjusted $R^{2}$ sebesar 0,625. Artinya $62,5 \%$ kinerja pegawai dipengaruhi oleh kompetensi, insentif dan disiplin. Sedangkan 37,5\% adalah variabel lain di luar dari variabel penelitian, seperti lingkungan kerja, motivasi dan lain-lain.

\section{Pembahasan}

Berdasarkan hasil uji $\mathrm{F}$ memperlihatkan kompetensi, insentif dan disiplin secara signifikan dan simultan mempengaruhi kinerja pegawai Balai PSDA Bengawan Solo. Hal ini didasarkan pada hasil penelitian yang dapat dilihat dari $F_{\text {hitung }}$ sebesar 43,197 dan signifikansinya $<0,05$ yaitu 0,000. Hasil tersebut membuktikan bahwa semakin tinggi kompetensi, insentif dan disiplin maka kinerja pegawai Balai PSDA Bengawan Solo akan mengalami peningkatan secara nyata.

Berdasarkan analisis uji t diperoleh kompetensi berpengaruh positif dan signifikan pada kinerja pegawai Balai PSDA Bengawan Solo. Hal ini didasarkan pada hasil $t_{\text {hitung }}$ yaitu sebesar 6,216 , koefisien regresi bernilai 0,586 dan signifikansinya $<0,05$ yaitu 0,000 . Artinya apabila pola kompetensi yang ada semakin tinggi, maka kinerja pegawai Balai PSDA Bengawan Solo akan meningkat. Balai PSDA Bengawan Solo harus dapat meningkatkan kompetensi yang dimiliki pegawai dengan melaksanakan pelatihan secara kontinu. Hasil ini mendukung penelitian Lasmaya (2016) kompetensi secara positif dan signifikan mempengaruhi kinerja pegawai.

Berdasarkan analisis uji t diperoleh insentif berpengaruh positif dan signifikan pada kinerja

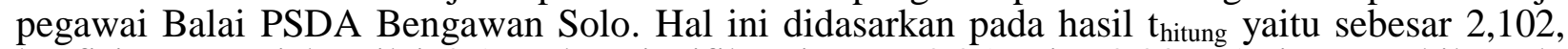
koefisien regresi bernilai 0,199 dan signifikansinya $<0,05$ yaitu 0,039. Artinya apabila pola insentif yang ada semakin tinggi, maka kinerja pegawai Balai PSDA Bengawan Solo akan meningkat. Pemberian insentif yang tepat dapat meningkatkan semangat kerja para pegawai sehingga hal ini dapat meningkatkan kinerja pegawai. Hasil ini mendukung penelitian Candrawati, et al (2013) insentif secara positif dan signifikan mempengaruhi kinerja pegawai.

Berdasarkan analisis uji t diperoleh disiplin berpengaruh positif dan signifikan pada kinerja

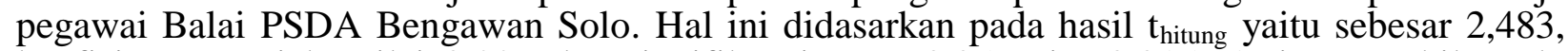
koefisien regresi bernilai 0,227 dan signifikansinya $<0,05$ yaitu 0,015. Artinya apabila pola disiplin yang ada semakin tinggi, maka kinerja pegawai Balai PSDA Bengawan Solo akan meningkat. Semakin tingginya disiplin kerja yang dimiliki oleh pegawai dengan adanya pemberian sanksi apabila ada yang melanggar peraturan perusahaan tanpa melihat posisi kerjanya akan mampu meningkatkan kinerja. Hasil ini mendukung penelitian Mananeke, et al (2014) disiplin secara positif dan signifikan mempengaruhi kinerja pegawai. 


\section{KESIMPULAN}

Kesimpulan dari penelitian ini adalah:

a. Kompetensi, insentif dan disiplin berpengaruh secara simultan dan signifikan terhadap kinerja pegawai Balai PSDA Bengawan Solo.

b. Kompetensi berpengaruh secara positif dan signifikan terhadap kinerja pegawai Balai PSDA Bengawan Solo.

c. Insentif berpengaruh secara positif dan signifikan terhadap kinerja pegawai Balai PSDA Bengawan Solo.

d. Disiplin berpengaruh secara positif dan signifikan terhadap kinerja pegawai Balai PSDA Bengawan Solo.

Selanjutnya Penulis memberikan saran antara lain:

a. Hendaknya Balai PSDA Bengawan Solo terus memberikan kebebasan kepada pegawainya untuk mengeksplorasi kompetensi yang dimiliki.

b. Hendaknya Balai PSDA Bengawan Solo meningkatkan kinerja pegawainya dengan pemberian insentif.

c. Hendaknya Balai PSDA Bengawan Solo meningkatkan penerapan disiplin kerja pada pegawai.

\section{DAFTAR PUSTAKA}

Arikunto, S. 2016. Metodologi Penelitian. Yogyakarta: Bina Aksara

Candrawati, Musadiq dan Hakam. 2013. Pengaruh Insentif Terhadap Kinerja Karyawan (Studi Kasus Karyawan Duta Catering-CV Darma Utama Batu). Jurnal Administrasi Bisnis Volume 1 diakses pada tanggal 16 November 2018 Jam 21.25

Lasmaya, S M. 2016. Pengaruh Sistem Informasi SDM, Kompetensi dan Disiplin Kerja Terhadap Kinerja Karyawan. Jurnal Ekonomi, Bisnis dan Enterpreneurship Volume 10 Nomor 1 diakses pada tanggal 18 November 2018 Jam 22.02

Mananeke, Katiandago, dan Mandey. 2014. Pengaruh Disiplin Kerja Kepemimpinan dan Motivasi Terhadap Kinerja Pegawai Pada PT. PLN (Persero) Wilayah Suluttenggo Area Manado. Jurnal Administrasi Bisnis diakses pada tanggal 18 November 2018 Jam 20.22

Prihantoro, A. 2012. Peningkatan Kinerja Sumber Daya Manusia Melalui Motivasi, Disiplin, Lingkungan kerja dan Komitmen (Studi Kasus Madrasah di Lingkungan Yayasan Salafiah, Kajen, Margoyoso, Pati). Jurnal Administrasi Bisnis Volume 8 Nomor 2 diakses pada tanggal 16 November 2018 Jam 21.01

Sutrisno, E. 2014. Manajemen Sumber Daya Manusia. Jakarta 